\title{
PENINGKATAN PENGGUNAAN MEDIA SOSIAL MENGGUNAKAN PRINSIP ANDRAGOGI DI DESA CIHANJUANG
}

\section{IMPROVING SOCIAL MEDIA UTILIZATION USING THE PRINCIPLES OF ANDRAGOGY IN CIHANJUANG VILLAGE}

\author{
D Hamidin 1a, W Resdiana1 , M N Fauzan1 \\ ${ }^{1}$ Politeknik Pos Indonesia, Jl. Sari Asih No. 54 Bandung 40151, Jawa Barat, Indonesia \\ aKorespondensi: Dini Hamidin ; E-mail: Dinihamidin@Poltekpos.ac.id \\ (Diterima: 31-10-2019; Ditelaah: 01-11-2019; Disetujui: 15-07-2020)
}

\begin{abstract}
Utilization of Social Media (Facebook and Instagram) can be used as a communication tool and introduction of village potentials both to wider societies and communities and private institutions. Cihanjuang Village is the third largest village in Parongpong District, West Bandung Regency. Based on Google search engine results, the information regarding the activities and the potentials of Cihanjuang Village is still very limited. Cihanjuang Village has not utilized the social media (Facebook and Instagram). To increase the awareness of the importance of using social media and optimize the utilization social media as village information media (investment potential, village activities and tourism), this community training is conducted. The training provides motivation and optimizes content management on social media. It was conducted using the ADDIE (Analysis, Design, Develop, Implement, Evaluate) model and the learning process adopted andragogi method. The results of the activities are 1) The Village Officials, PKK Cadres and Youth Organization have the knowledge, skills and interests to optimize social media for the dissemination of information on Cihanjuang Village government service activities (administrative and non-administrative), activities in every field in Cihanjuang Village administration, news dissemination and village potential; 2) The results of the training can be realized with the development of social media Instagram and Facebook Cihanjuang Village whose news content packaging is more informative as a medium for information, communication and product promotion and potential of Cihanjuang Village along with the official website link of Cihanjuang Village.
\end{abstract}

Keywords: Cihanjuang Village, Social Media, ADDIE Model, Andragogi Method

\begin{abstract}
ABSTRAK
Pemanfaatan media sosial (Facebook dan Instagram) dapat digunakan sebagai alat komunikasi dan memperkenalkan potensi Desa baik dengan masyarakat luas maupun dengan komunitas dan lembaga swasta. Desa Cihanjuang merupakan desa dengan luas wilayah ketiga terbesar di Kecamatan Parongpong Kabupaten Bandung Barat. Berdasarkan hasil pencarian melalui google search engine, informasi terkait kegiatan dan potensi Desa Cihanjuang masih sangat terbatas, Desa Cihanjuang belum mememanfaatkan media sosial (facebook dan instagram). Untuk meningkatkan kesadaran pentingnya memiliki dan menggunakan media sosial dan mengoptimalkan penggunaan media sosial sebagai media informasi Desa (potensi investasi, kegiatan Desa dan wisata), maka pengabdian kepada masyarakat ini dilakukan pelatihan. Pelatihan ini memberikan motivasi dan optimalisasi pengelolaan konten di media sosial. Pelaksanaan pelatihan ini dilakukan dengan menggunakan model ADDIE (Analysis, Design, Develop, Implement, Evaluate) dan proses pembelajarannya mengadopsi metode andragogi. Hasil dari pelaksanaan kegiatan ini adalah 1) Para Perangkat Desa, Kader PKK dan Karang Taruna memiliki pengetahuan, keterampilan dan ketertarikan untuk mengoptimalkan media sosial untuk penyebaran informasi kegiatan pelayanan pemerintahan Desa Cihanjuang (administrasi dan non administrasi), kegiatan setiap bidang di pemerintahan Desa Cihanjuang, penyebaran berita dan potensi desa; 2) Hasil pelatihan telah dapat
\end{abstract}


diwujudkan dengan terbangunnya media sosial Instagram dan facebook Desa Cihanjuang yang kemasan konten beritanya lebih informatif sebagai media informasi, komunikasi dan promosi produk dan potensi Desa Cihanjuang disertai link website resmi Desa Cihanjuang.

Kata kunci: Desa Cihanjuang, Media Sosial, Model ADDIE, Metode Andragogi.

Humidin, D., Resdiana, W., Fauzan, M. N. (2020).Peningkatan Penggunaan Media Sosial Menngunakan

Prinsip Andragogi di Desa Cihanjuang. Jurnal Qardhul Hasan : Media Pengabdian kepada Masyarakat, 6(2), 88-96.

\section{PENDAHULUAN}

Salah satu prinsip dasar untuk meningkatkan perekonomian di pedesaan menurut situs berdesa.com adalah memajukan potensi desa. Dimana caranya adalah dengan mempermudah akses informasi terkait pendanaan usaha, pelatihan, mengembangkan produk usaha masyarakat dan mengelola sektor pemasaran. Hal ini sejalan dengan visi Provinsi Jawa Barat yang fokus pada desa digital, yang bertujuan untuk meningkatkan perekonomian masyarakat dan kualitas warga desa atau wilayah pinggiran kota kecil. Berdasarkan survey APJII tahun 2017, pengguna internet di Indonesia telah mencapai 143,26 jiwa atau $\pm 50 \%$ dari penduduk Indonesia. Penetrasi pengguna internet di pedesaan telah mencapai $48,25 \%$, artinya hampir setengah masyarakat dari desa-desa yang ada di Indonesia telah mengenal internet. Semakin meningkatnya pengguna internet tidak terlepas dari perangkat komputer/smartphone/tablet yang kian terjangkau. Survey APJII menyatakan bahwa akses layanan sosial media menjadi layanan yang paling tinggi $(87,13 \%)$ diikuti oleh layanan lihat gambar/foto $(72,79 \%)$, lihat video $(69,64 \%)$ dan layanan artikel $(55,30 \%)$.

Tersedianya sarana akses digital di desa Cihanjuang belum dimanfaatkan secara dioptimalkan. Berdasarkan pencarian melalui internet, baik melalui media sosial (Instagram dan facebook) maupun melalui mesin pencari masih sulit ditemukan berita lengkap baik mengenai kegiatan di Desa Cihanjuang maupun bisnis Usaha Kecil Menengah (UKM), produk serta potensi unggulan yang dimiliki oleh Desa
Cihanjuang. Media sosial Instagram belum dimanfaatkan secara optimal baik oleh perangkat desa, Karang Taruna, BumDes, PKK maupun lembaga desa lainnya. Kata "Desa Cihanjuang Kecamatan Parongpong" hanya ditemukan dalam bentuk hashtag dengan nama "\#desacihanjuang" yang banyak digunakan oleh masyarakat desa untuk menandai tempat dimana mereka berada, tetapi belum ditemukan Instagram resmi dari Desa Cihanjuang itu sendiri. Dengan adanya hashtag tersebut, menandakan bahwa masyarakat Desa Cihanjuang sudah berkomunikasi melalui Instagram. Hal ini menjadi satu peluang bagi Desa Cihanjuang untuk mengoptimalkan komunikasi dengan berbagai kalangan masyarakat, baik masyarakat di luar desa maupun masyarakat di Desa Cihanjuang itu sendiri melalui media sosial Instagram.

Berdasarkan pemaparan di atas, maka perlu untuk dilakukan pelatihan dalam rangka mengoptimalkan media sosial untuk meningkatkan akses dan penyebaran informasi Desa Cihanjuang. Tujuan dari pelatihan ini adalah meningkatkan penggunaan media sosial sebagai media informasi Desa dan promosi potensi desa, sehingga Desa cihanjuang dapat lebih dikenal dan mempermudah akses informasi dan komunikasi desa. Menurut Hasan dan Setiyaningtiyas (2015), media sosial memiliki pengaruh yang positif untuk menciptakan komunikasi dari mulut ke mulut secara online. Komunikasi ini bisa dalam bentuk melakukan likers, membalas posting ataupun review. Selain itu juga menigkatkan kesadaran perangkat desa untuk dapat secara aktif berkelanjutan memberikan informasi positif dan melakukan komunikasi secara digital mengenai kegiatan dan program desanya. 
Salah satu prinsip dasar untuk meningkatkan perekonomian di pedesaan menurut situs berdesa.com adalah memajukan potensi desa. Dimana caranya adalah dengan mempermudah akses informasi terkait pendanaan usaha, pelatihan, mengembangkan produk usaha masyarakat dan mengelola sektor pemasaran. Hal ini sejalan dengan visi Provinsi Jawa Barat yang fokus pada desa digital, yang bertujuan untuk meningkatkan perekonomian masyarakat dan kualitas warga desa atau wilayah pinggiran kota kecil. Berdasarkan survey APJII tahun 2017, pengguna internet di Indonesia telah mencapai 143,26 jiwa atau $\pm 50 \%$ dari penduduk Indonesia. Penetrasi pengguna internet di pedesaan telah mencapai $48,25 \%$, artinya hampir setengah masyarakat dari desa-desa yang ada di Indonesia telah mengenal internet. Semakin meningkatnya pengguna internet tidak terlepas dari perangkat komputer/smartphone/tablet yang kian terjangkau. Survey APJII menyatakan bahwa akses layanan sosial media menjadi layanan yang paling tinggi $(87,13 \%)$ diikuti oleh layanan lihat gambar/foto $(72,79 \%)$, lihat video $(69,64 \%)$ dan layanan artikel $(55,30 \%)$.

Tersedianya sarana akses digital di desa Cihanjuang belum dimanfaatkan secara dioptimalkan. Berdasarkan pencarian melalui internet, baik melalui media sosial (Instagram dan facebook) maupun melalui mesin pencari masih sulit ditemukan berita lengkap baik mengenai kegiatan di Desa Cihanjuang maupun bisnis Usaha Kecil Menengah (UKM), produk serta potensi unggulan yang dimiliki oleh Desa Cihanjuang. Media sosial Instagram belum dimanfaatkan secara optimal baik oleh perangkat desa, Karang Taruna, BumDes, PKK maupun lembaga desa lainnya. Kata "Desa Cihanjuang Kecamatan Parongpong" hanya ditemukan dalam bentuk hashtag dengan nama "\#desacihanjuang" yang banyak digunakan oleh masyarakat desa untuk menandai tempat dimana mereka berada, tetapi belum ditemukan Instagram resmi dari Desa Cihanjuang itu sendiri. Dengan adanya hashtag tersebut, menandakan bahwa masyarakat Desa Cihanjuang sudah berkomunikasi melalui Instagram. Hal ini menjadi satu peluang bagi Desa Cihanjuang untuk mengoptimalkan komunikasi dengan berbagai kalangan masyarakat, baik masyarakat di luar desa maupun masyarakat di Desa Cihanjuang itu sendiri melalui media sosial Instagram.

Berdasarkan pemaparan di atas, maka perlu untuk dilakukan pelatihan dalam rangka mengoptimalkan media sosial untuk meningkatkan akses dan penyebaran informasi Desa Cihanjuang. Tujuan dari pelatihan ini adalah meningkatkan penggunaan media sosial sebagai media informasi Desa dan promosi potensi desa, sehingga Desa cihanjuang dapat lebih dikenal dan mempermudah akses informasi dan komunikasi desa. Menurut Hasan dan Setiyaningtiyas (2015), media sosial memiliki pengaruh yang positif untuk menciptakan komunikasi dari mulut ke mulut secara online. Komunikasi ini bisa dalam bentuk melakukan likers, membalas posting ataupun review. Selain itu juga menigkatkan kesadaran perangkat desa untuk dapat secara aktif berkelanjutan memberikan informasi positif dan melakukan komunikasi secara digital mengenai kegiatan dan program desanya. Salah satu prinsip dasar untuk meningkatkan perekonomian di pedesaan menurut situs berdesa.com adalah memajukan potensi desa. Dimana caranya adalah dengan mempermudah akses informasi terkait pendanaan usaha, pelatihan, mengembangkan produk usaha masyarakat dan mengelola sektor pemasaran. Hal ini sejalan dengan visi Provinsi Jawa Barat yang fokus pada desa digital, yang bertujuan untuk meningkatkan perekonomian masyarakat dan kualitas warga desa atau wilayah pinggiran kota kecil. Berdasarkan survey APJII tahun 2017, pengguna internet di Indonesia telah mencapai 143,26 jiwa atau $\pm 50 \%$ dari penduduk Indonesia. Penetrasi pengguna internet di pedesaan telah mencapai 
48,25\%, artinya hampir setengah masyarakat dari desa-desa yang ada di Indonesia telah mengenal internet. Semakin meningkatnya pengguna internet tidak terlepas dari perangkat komputer/smartphone/tablet yang kian terjangkau. Survey APJII menyatakan bahwa akses layanan sosial media menjadi layanan yang paling tinggi $(87,13 \%)$ diikuti oleh layanan lihat gambar/foto $(72,79 \%)$, lihat video $(69,64 \%)$ dan layanan artikel $(55,30 \%)$.

Tersedianya sarana akses digital di desa Cihanjuang belum dimanfaatkan secara dioptimalkan. Berdasarkan pencarian melalui internet, baik melalui media sosial (Instagram dan facebook) maupun melalui mesin pencari masih sulit ditemukan berita lengkap baik mengenai kegiatan di Desa Cihanjuang maupun bisnis Usaha Kecil Menengah (UKM), produk serta potensi unggulan yang dimiliki oleh Desa Cihanjuang. Media sosial Instagram belum dimanfaatkan secara optimal baik oleh perangkat desa, Karang Taruna, BumDes, PKK maupun lembaga desa lainnya. Kata "Desa Cihanjuang Kecamatan Parongpong" hanya ditemukan dalam bentuk hashtag dengan nama "\#desacihanjuang" yang banyak digunakan oleh masyarakat desa untuk menandai tempat dimana mereka berada, tetapi belum ditemukan Instagram resmi dari Desa Cihanjuang itu sendiri. Dengan adanya hashtag tersebut, menandakan bahwa masyarakat Desa Cihanjuang sudah berkomunikasi melalui Instagram. Hal ini menjadi satu peluang bagi Desa Cihanjuang untuk mengoptimalkan komunikasi dengan berbagai kalangan masyarakat, baik masyarakat di luar desa maupun masyarakat di Desa Cihanjuang itu sendiri melalui media sosial Instagram.

Berdasarkan pemaparan di atas, maka perlu untuk dilakukan pelatihan dalam rangka mengoptimalkan media sosial untuk meningkatkan akses dan penyebaran informasi Desa Cihanjuang. Tujuan dari pelatihan ini adalah meningkatkan penggunaan media sosial sebagai media informasi Desa dan promosi potensi desa, sehingga Desa cihanjuang dapat lebih dikenal dan mempermudah akses informasi dan komunikasi desa. Menurut Hasan dan Setiyaningtiyas (2015), media sosial memiliki pengaruh yang positif untuk menciptakan komunikasi dari mulut ke mulut secara online. Komunikasi ini bisa dalam bentuk melakukan likers, membalas posting ataupun review. Selain itu juga menigkatkan kesadaran perangkat desa untuk dapat secara aktif berkelanjutan memberikan informasi positif dan melakukan komunikasi secara digital mengenai kegiatan dan program desanya.

\section{MATERI DAN METODE}

Model ADDIE adalah Analyze, Design, Development, Implementation dan Evaluate yang diperkenalkan oleh Branch (2009), banyak digunakan untuk pengembangan pembelajaran, seperti yang dilakukan dalam papernya Prastati (2014) yang mengembangkan program pelatihan tatap muka dengan menggunakan model ADDIE. Taçgin \& Erim Güner (2014) menyatakan bahwa model ADDIE menggambarkan peta jalan yang harus diikuti (merancang dengan instruksional) dalam mempersiapkan bahan pelatihan. Merancang dengan instruksional, dimana menurut Aldoobie (2015) artinya adalah bahwa proses yang secara sistematis membantu menciptakan dan mengembangkan secara efektif, menarik dan material instruksi yang efisien dalam lingkungan yang mendukung menggunakan seni, sains, belajar dan teori pembelajaran.

Perancangan instruksi Model ADDIE terdiri dari 4 komponen (Aldoobie, 2015), yaitu: 1) Analyze (permasalahan dan kebutuhan pembelajar); 2) Design (analisis kebutuhan dan masalah pembelajar, merancang aktivitas dan materi); 3) Development (pengembangan materi untuk mencapai tujuan sesuai dengan yang dibutuhkan pembelajar);

Implementation (pelaksanaan pelatihan); 5) Evaluate (hasil belajar). Peningkatan penggunaan media sosial ini mengadopsi empat komponen model ADDIE tersebut.

Peserta kegiatan ini adalah orang-orang dewasa dimana mereka merupakan bagian 
dari perangkat desa, lembaga Desa seperti PKK, Karang Taruna, Bumdes. Menurut Kapur (2015) Pembelajar orang dewasa (Andragogy) memiliki karakteristik yang berbeda dan unik. Mereka dewasa, mandiri, memiliki kekayaan pengetahuan dan pengalaman. Sehingga, pembelajaran orang dewasa adalah pendidikan yang sederajat (fasilitator dan pelajar). Dr. Sujarwo, M.Pd. (2012) menyatakan ada empat utama hal utama yang harus dipertimbangkan dalam pembelajaran orang dewasa, yaitu: 1) Konsep diri; 2) pengalaman; 3) Kesiapan untuk belajar; 4) Berorientasi ke arah kegiatan belajar. Berdasarkan Piramida belajar (pyramid of learning) bahwa orang dewasa belajar lebih efektif dengan mendengarkan (ceramah) dan berbicara (diskusi); lebih baik jika dapat melihat (demonstrasi); makin efektif dengan mengerjakan (latihan praktis) (Surdaryanto, 2016). Metode yang dikembangkan pada peningkatan penggunaan media sosial ini menggunakan prinsip andragogy yang dapat digambarkan sebagai berikut:

Gambar 1. Metode Pelaksanaan Pelatihan di Desa Cihanjuang.

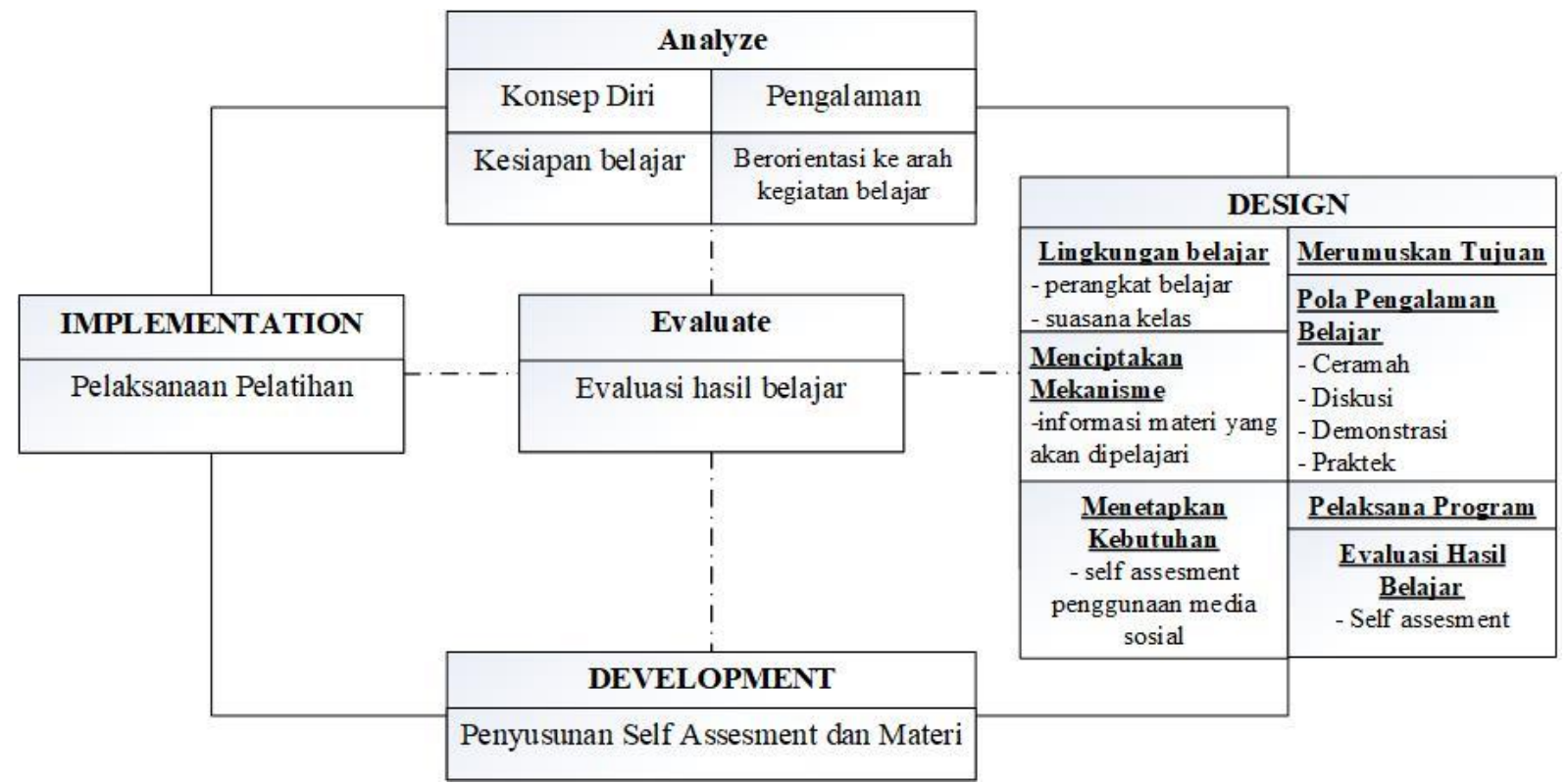

\section{HASIL DAN PEMBAHASAN}

Pelatihan penggunaan media sosial ini dilaksanakan di kantor Desa Cihanjuang Parongpong Kabupaten Bandung Barat diikuti oleh 19 orang, yang terdiri dari 5 orang perangkat desa, 2 orang kader PKK dan 7 orang Karang Taruna. Pelatihan ini dipandu oleh tiga orang pelaksana selaku fasilitator yang dibantu oleh 4 orang mahasiswa selaku asisten pelaksana.

Pelaksanaan kegiatan pelatihan ini terdiri dari 4 materi yang diberikan secara sistematis, yaitu:

Materi Media Sosial untuk Informasi Desa, yang berisi: bagaimana desa dapat memasarkan diri melalui media sosial, dampak yang didapatkan desa dan contoh- contoh desa yang sudah menerapkan media sosial sebagai media informasi, komunikasi dan pemasaran desa

Materi Teknik Dokumentasi untuk Media Sosial, yang berisi: fungsi foto di media sosial, teknik pengambilan gambar, membuat foto dokumentasi, dan tutorial melakukan editing gambar melalui smartphone

Materi Pembuatan fanpage di Facebook dan Instagram bisnis, yang berisi: tutorial langkah-langkah membuat fanpage di facebook dan Instagram bisnis

Materi Cara Membuat Konten Akun Bisnis dan Facebook Fanpage, yang berisi: bagaimana melakukan penulisan konten di facebook maupun Instagram beserta contoh-contoh penulisan konten about, berita dan informasi. 
Sebelum pelatihan dimulai, peserta diberikan kuesioner awal yang berisi self assessment untuk dapat mengetahui sejauh mana pengetahuan dan ketertarikan peserta terkait media sosial dan penggunaannya. Setelah kuesioner awal selesai dikerjakan, pelatihan baru dimulai. Pelatihan diakhiri oleh pengisian kuesioner kembali sebagai self assessment peserta untuk dapat mengetahui sejauhmana tingkat perubahan pengetahuan dan ketertarikan peserta terkait media sosial dan penggunaannya. Materi yang diberikan dalam bentuk ceramah, tutorial dan praktek yang diselimgi oleh diskusi secara interaktif. Hasil dari pelatihan tersebut, para peserta sudah Gambar 3. Grafik Hasil Kuesioner deft Assement Awal

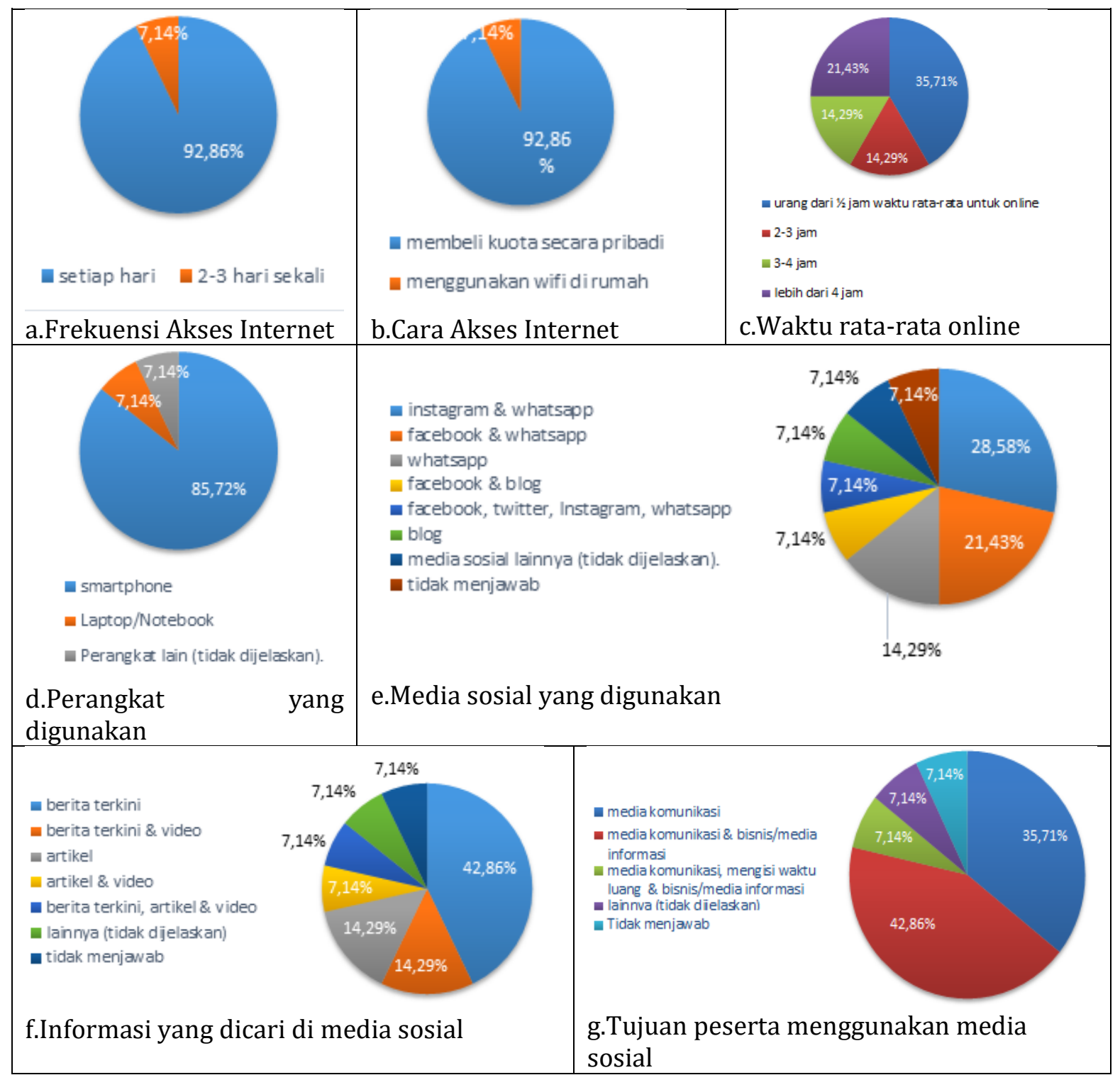

dapat membuat Instagram bisnis sendiri dengan isi konten yang lebih informatif. Gambar 2. Pelaksanaan Pelatihan Media Sosial.

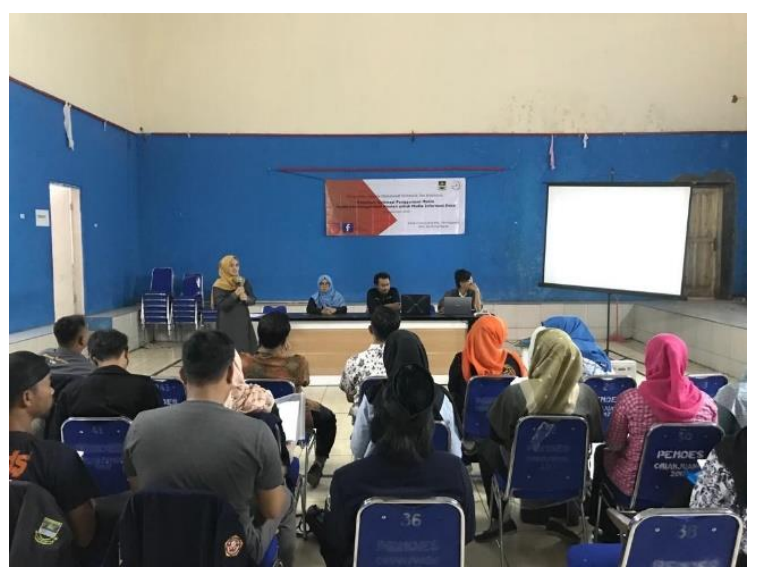




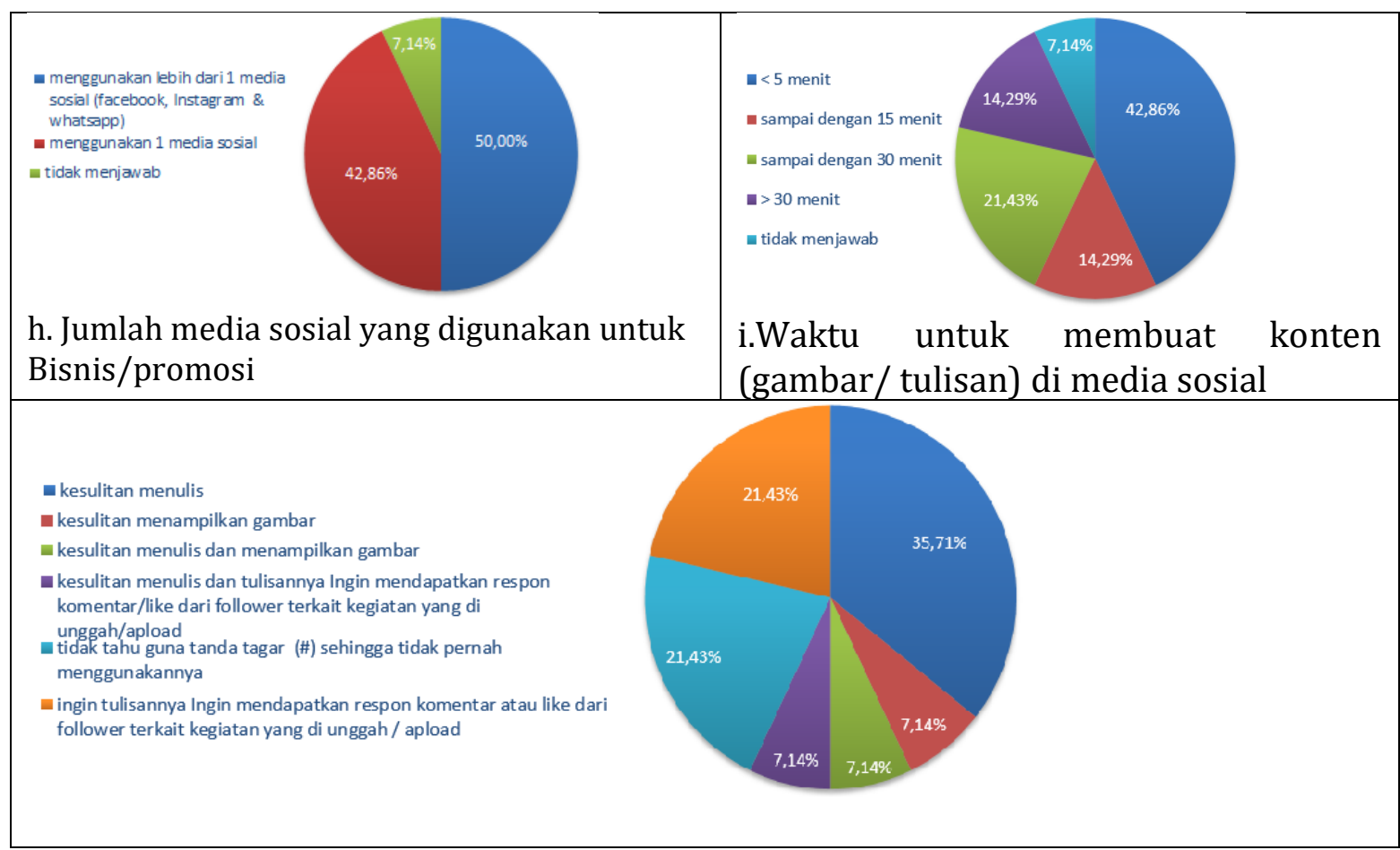

Berdasarkan gambar 3 di atas
menunjukkan, bahwa peserta yang mengikuti pelatihan sudah memiliki kebiasaan untuk mengakses informasi melalui internet. Dalam melakukan akses internet, peserta sudah memiliki anggaran/budget tersendiri sebagai biaya untuk mengakses internet. Mereka memeiliki keterbatasan waktu untuk online, ini mungkin saja terkait dengan aktivitas pekerjaan di kantor maupun di rumah. Namun tidak menutup kemungkinan juga, hal ini disebabkan oleh terbatasnya kuota yang dimiliki oleh setiap orang tersebut. Hampir semua peserta menggunakan smartphone dimana mereka memiliki fleksibilitas untuk terkoneksi dengan internet. Sehingga, sebenarnya mereka dapat mengirimkan informasi setiap kegiatan/aktivitas berlangsung di Desa Cihanjuang melalui smartphone.

Berdasarkan poin e pada gambar 3, semua peserta sebenarnya sudah menggunakan media sosial, hanya saja semuanya masih digunakan untuk kepentingan pribadi, belum dimanfaatkan untuk pembangunan dan promosi desa-nya. Sebagian besar masih mencari berita terkini atau yang sedang viral, dimana hal tersebut masih menjadi informasi yang menarik. Selain itu, media sosial juga digunakan sebagai media komunikasi dan juga bisnis/media informasi secara pribadi. Dalam kegiatan bisnisnya, hampir semua peserta telah menggunakan lebih dari 1 media sosial. Berdasarkan poin i, jika dikumulatifkan, maka hampir 50\% dari peserta masih memiliki waktu yang cukup lama (> 30 menit) untuk menghasilkan konten baik gambar maupun tulisan di media sosial. Peserta juga merasa bahwa mereka masih belum optimal dalam melakukan upload penulisan dan gambar yang menarik dan informatif serta dapat direspon oleh banyak follower.

\section{Self Assesment Akhir}

Berdasarkan hasil kuesioner self assesment akhir, maka setelah pelatihan dilaksanakan semua peserta (perangkat desa, kader PKK dan karang taruna) 100\% telah memahami bagaimana mengoptimalkan media sosial (Instagram dan facebook), yaitu melalui penulisan isi/konten, mengolah tampilan foto/gambar dan mengoptimalkan penggunaan tanda tagar \#. Mereka tertarik memanfaatkan media sosial (seperti Instagram dan facebook) secara optimal untuk kepentingan dan kemajuan Desa Cihanjuang dan mereka menyadari bahwa Desa Cihanjuang perlu untuk memiliki dan memanfaatkan media sosial (seperti 
Instagram dan facebook) agar Desa Cihanjuang lebih dikenal oleh masyarakat luas terkait kegiatan, potensi dan pembangunan di Desa Cihanjuang. Peserta menyadari dampak positif akan dirasakan jika desa dikenal oleh masyarakat luas.

Berdasarkan hasil pelaksanaan pengabdian kepada masyarakat di Desa Cihanjuang ini dan berdasarkan perangkat evaluasi (kuesioner), maka para peserta, baik perangkat Desa, kader PKK maupun karang taruna telah memiliki:

Tingkat pengetahuan yang sama terkait pentingnya mengoptimalkan media sosial (seperti Instagram dan facebook) untuk kepentingan dan kemajuan Desa Cihanjuang Tingkat keterampilan yang sama terkait penulisan isi/konten, mengolah tampilan dan foto/gambar serta kegunaan tanda tagar \# di media sosial.

Ketertarikan yang sama dalam memanfaatkan media sosial untuk kepentingan promosi dan penyebaran informasi terkait Informasi Desa Cihanjuang, kegiatan pelayanan pemerintahan desa Cihanjuang (administrasi dan non administrasi), kegiatan setiap bidang di pemerintahan Desa Cihanjuang, penyebaran berita dan potensi desa, sehingga Desa Cihanjuang lebih dikenal oleh masyarakat luas.

Selain dilakukan evaluasi terhadap hasil pelatihan, untuk keberlanjutan program pengabdian kepada masyarakat di Desa Cihanjuang ini, dilakukan monitoring terhadap media sosial Desa Cihanjuang. Hasil monitoring menunjukkan bahwa saat ini Desa Cihanjuang telah memiliki media sosial Instagram (dengan 90 followers dan 90 following) dan facebook yang memilili link ke website Desa Cihanjuang, media sosial Desa Cihanjuang berisi: 1) Informasi letak Desa secara lengkap; 2) Kegiatankegiatan seperti bakti sosial, kegiatan pelatihan, pemilihan ketua RW dan video karnaval; 3) Link website Desa Cihanjuang Tentunya informasi-informasi tersebut belum cukup untuk memperlihatkan potensi dan pembangunan di Desa Cihanjuang. Wahyono (2011), menyatakan bahwa keberhasilan desa dalam melakukan layanan informasi yang mencerdaskan, memberdayakan dan meningkatkan ekonomi masyarakat perdesaan perlu memiliki komitmen untuk menjadikan desanya sebagai desa informasi; memiliki keinginan untuk maju yang didukung oleh warganya. Sehingga, perlu komitmen dari seluruh komponen di Desa Cihanjuang, baik perangkat Desa, Kader PKK, Karang taruna dan stakeholder lainnya yang ada di Desa Cihanjuang.

Gambar 4. Facebook dan Instragram Desa Cihanjuang.

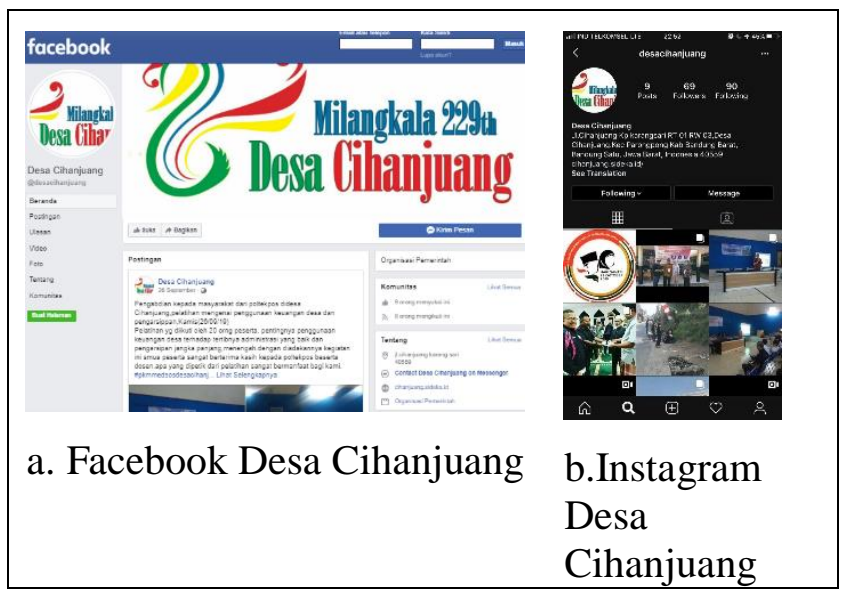

Capacity Building dapat mendorong organisasi agar dapat berjalan sesuai dengan fungsinya, serta menciptakan kondisi lingkungan yang dibutuhkan oleh organisasi serta dalam melaksanakan tugasnya akan terjalin kerjasama (Rahmawati \& Nugroho, 2018). Begitu juga peningkatan kapasitas keterampilan berkomunikasi melalui media sosial ini dapat digunakan sebagai satu strategi untuk meningkatkan Desa Cihanjuang semakin maju, dikenal dan meningkatkan kerjasama dengan berbagai instansi pemerintah lainnya dan swasta.

\section{KESIMPULAN}

Berdasarkan hasil pelaksanaan pengabdian kepada masyarakat di Desa Cihanjuang Kecamatan Parongpong Kabupaten Bandung Barat, maka dapat disimpulkan bahwa: $82,6 \%$ atau 19 orang yang terdiri dari Perangkat Desa, Kader PKK dan Karang Taruna telah mengikuti pelatihan 
optimalisasi penggunaan media sosial dan pengelolaan konten (terkait penulisan isi/konten, mengolah tampilan dan foto/gambar serta kegunaan tanda tagar \# di media sosial) untuk media informasi Desa di Desa Cihanjuang parongpong Bandung Barat. Semua peserta telah memiliki tingkat pengetahuan, keterampilan dan ketertarikan untuk mengoptimalkan media sosial (seperti Instagram dan facebook) untuk penyebaran informasi link website Desa Cihanjuang, kegiatan pelayanan pemerintahan desa Cihanjuang (administrasi dan non administrasi), kegiatan setiap bidang di pemerintahan Desa Cihanjuang, penyebaran berita dan potensi desa, sehingga Desa Cihanjuang lebih dikenal oleh masyarakat luas.

Dampak dari kegiatan ini telah dapat diwujudkan dengan terbangunnya media sosial Instagram Desa Cihanjuang yang kemasan konten beritanya lebih informatif sebagai media informasi, komunikasi dan promosi produk dan potensi Desa Cihanjuang.

\section{UCAPAN TERIMAKASIH}

Terima kasih kepada LPPM Politeknik Pos Indonesia atas hibah PKM Internal yang telah diberikan. Terima kasih juga kepada Seluruh aparatur pemerintahan Desa Cihanjuang Kecamatan Parongpong Kabupaten Bandung.

\section{DAFTAR PUSTAKA}

Branch, Robert Maribe. (2009). Instructional Design: ADDIE Approach. New York: Springer.

Dr. Sujarwo, M.Pd., 2012. Strategi Pembelajaran Orang Dewasa (Pendekatan Andragogi), Jurusan Pendidikan Luar Sekolah, Fakultas Ilmu Pendidikan, Universitas Negeri Yogyakarta.

Prastati, Trini. (2014). Teaching And Learning In The 21ST Century:
Challenges for Lecturers and Teachers. Professional Development in Education (PDE).

Taçgin, Zeynep \& Erim Gűner, Nilay. (2014). ADDIE Model in Adult Education: Instructional Design Sample of ELearning. Conference $5^{\text {th }}$ International Future-Learning Conference on Innovation in Learning for the Future 2014: e-Learning, At Instanbul.

Aldoobie, Nada. (2015). ADDIE Model. American International Journal of Contemporary Research Vol. 5, No. 6; December 2015.

Hasan, A., \& Setiyaningtiyas, N. W. 2015. Pengaruh Electronic Word of Mouth pada Media Sosial Facebook terhadap Keputusan Berkunjung ke Desa Wisata Nglanggeran Gunungkidul. Jurnal Media Wisata: Wahana Informasi Pariwisata, 13(1).

Kapur, Sikha. (2015). Andragogy: The Adult Learning Theory. Indian Journal of Adult Education vo. 76, No. 2, April June 2015.

Sudaryanto, D. H. (2016). Pendekatan prinsip adult learning dalam upaya menunjang proses pembelajaran diklat aparatur. Tersedia online pada http://pusdiklatmigas. esdm. go. id/portal_jurnal/readmore/165.

Rahmawati, A., \& Nugroho, H. S. (2018). Capacity Building Pada Unit Program Pembinaan Kesejahteraan Keluarga ( Pkk ) Capacity Building In The Family Welfare Program ( Pkk ). 4(April), 4147.

Asosiasi Penyelenggara Jasa Internet Indonesia (APJII). (2017). Infografis Penetrasi 6 Perilaku Pengguna Internet Indonesia, Survey 2017.

-.2018. Prinsip Dasar yang Wajib Dipegang Untuk Meningkatkan Perekonomian di Pedesaan.

http://www.berdesa.com/meningkatkanperekonomian-di-pedesaan/. Diakses tanggal 20 September 2019. 